\title{
Do Democracy and Free Markets Protect Us From Terrorism?
}

\author{
James A. Piazza \\ Department of Political Science, University of North Carolina at Charlotte, 9201 University City \\ Blvd. Charlotte, Charlotte, NC 28223, USA. \\ E-mail: jpiazza@uncc.edu
}

This study empirically tests what has become a central component of US antiterrorism policy under the Bush administration: that terrorism is a byproduct of illiberal political and economic systems. Employing a series of statistical analyses on incidents of terrorism in 153 countries from 1986 to 2003, the author finds that variables measuring democracy and degree of economic openness are not significant predictors of terrorism. However, the study does find that experience of state failures is significant, thus providing empirical backing for a small, descriptive body of scholarship linking failed states to terrorism.

International Politics (2007) 45, 72-91. doi:10.1057/palgrave.ip.8800220

Keywords: terrorism; democracy; free markets; anti-terrorism policy

\section{Introduction}

Part of winning the war on terror is spreading freedom and democracy. (George W. Bush, June 1, 2004)

A key plank in the Bush Administration's anti-terrorism policy, the 'War on Terror,' is the promotion, at least rhetorically, of democratic governance and free market economic policies in those parts of the world characterized by political repression and illiberal economies. Political dictatorships and economically closed societies, the administration has consistently maintained, pose a grave threat to international security because they are incubators for transnational terrorism. The antidote, it follows, is economic and political liberalization by whatever possible means on the part of the United States and its allies in the War on Terror. A 2002 report from the White House entitled 'The National Security Strategy of the United States of America' explains that only through the promotion of free trade, the advancement and universalization of free market economic reform and by, 'expanding the circle of development by opening societies and building the infrastructure of democracy,' can the United States meet the security challenges posed by terrorism (White House, 2002). Pointing to the 2001 removal of the Taliban 
government in Afghanistan by the United States and its allies and the successful implementation of orderly parliamentary elections in September of 2005, US Secretary of State Condoleezza Rice maintained that United States promotion of democratic transitions and fundamental economic reforms in Afghanistan and elsewhere was the key to defeating terrorism explaining, 'The Afghan people have an important role to play in defeating the terrorists... It is my hope that now with the parliamentary elections done that all Afghans will now see that the road ahead and the future is on the political front, not in violence' (Voice of America, 2005).

Faced in the Fall of 2004 with questions about the failure of United States and coalition forces to discover weapons of mass destruction in Iraq recalling that this was the original main justification for the 2003 US-led war that toppled the Ba'athist regime of Saddam Hussein - President Bush publicly maintained that the United States and the world were 'better off' without Saddam Hussein. The Hussein regime, the President explained, was an isolated, economically closed, politically rigid and repressive dictatorship that harbored at least the intent, if not the immediate capacity, to promote terrorism throughout the world by working with Al Qaeda and like-minded movements. Even when the relationship between the Ba'athist regime and Al Qaeda was disputed in a report issued in June 2004 by the independent National Commission on Terrorist Attacks, the so-called 9/11 Commission, President Bush persisted in defending regime change in Iraq, arguing that the removal of Saddam Hussein permitted the implantation of a democratic and economically free Iraq in the midst of a deeply undemocratic Arab World and that its example would be the catalyst for change throughout the region. In his statements from 2004 to 2007, the President continued to position political and economic freedom as a bulwark against terrorism and frequently lauded the progress towards democracy and free market reforms in Iraq, Afghanistan, Ukraine, Lebanon and the Palestinian Territories as hard evidence supporting what had become the dominant US anti-terrorism policy paradigm marrying political and economic liberalization with United States and world security (US Department of State, 2005; White House, 2007).

The President was joined in his statements by other key policymakers, foreign policy professionals and experts. Then Secretary of State Colin Powell explained, 'A shortage of economic opportunities is a ticket to despair. Combined with rigid political systems, it is a dangerous brew indeed' (Powell 2002). Republican congressman from Connecticut Christopher Shays identified both free markets and political 'self-determination' as 'major weapons' in the US anti-terrorism arsenal in a Washington Post editorial (Shays, 2003), while the former Senior Advisor to the Coalition Provisional Authority in Iraq, Larry Diamond, urged the United States to fund democracy promotion throughout the world to help create strong civil society actors that could force 
accountability on 'predatory' and 'bad' governments that, Diamond argued, were supporters of international terrorism (Diamond, 2002). Nobel laureates Milton Freedman and Gary Becker posited that, 'Economic freedom .... is also a tonic against terrorism because of the opportunities it creates,' and alleged that, 'All of the nations behind global terrorism lack economic freedom' (Fraser Institute, 2002). The 2002 Arab Development Report published by the United Nations Development Program (UNDP) concluded that the most significant problems of the Arab World, the most prominent being political violence, were rooted in a lack of freedom and paucity of economic opportunity suffered by its residents. The report advocated policies aimed at political and economic liberalization to solve the entrenched problems of the region which would, by extension, dampen violent conflicts of all types (United Nations Development Program, 2002).

Moreover, concrete policy initiatives within the United States were created to correspond with the foreign policy narrative linking the promotion of political and economic liberalization as a key defense against international terrorist attacks. In 2002, the Bush administration proposed a US\$ 5 billion Millennium Challenge Account that seeks to reward states with good governance records with development funds. ${ }^{1}$ Later in 2002, the US State Department announced a Middle East Partnership Initiative that would allocate US\$ 375 million over 3 years to promote the development of civil society actors, the private sector, educational reform and reform of women's rights (Windsor, 2003). Official US government documents and press releases boasted of its revitalized relations with pro-democracy dissidents targeting non-democratic regimes (US Department of State, 2005; White House, 2007). And within Iraq itself, the Bush Administration, through the Coalition Provisional Authority, sponsored two rounds of national elections and implemented quite radical programs to privatize Iraqi industry and liberalize Iraqi international trade, capital market, labor, environmental, public use and social welfare policies (Klein, 2004).

\section{The Theoretical Link Between Freedom and Terrorism}

But how might international terrorism, democracy and free market economies be logically related to one another? Few supporters of President Bush's postSeptember 11th anti-terrorism policy framework have clearly explained the causal mechanisms underlying such a relationship. American Enterprise Institute fellow Joshua Muravchik provides the most concrete explanation of how this relationship might work in an article published in the conservative Weekly Standard, though his theoretical model is explicitly confined to the political dimension of the relationship - the free market 
components are poorly described bedfellows of political reform - and is only applied to Muslim societies in the Middle East. Muravchik posits that the climate of 'unfreedom' that pervades most Middle Eastern countries breeds extremist thought and behavior that leads to terrorist activity. Regimes in the region, he notes, have traditionally used heavy doses of repression, replete with appalling human rights abuses, to control their public, and are characterized by a legacy of formidable state-led economic development, largely undisturbed by the wave of neo-liberal economic reform that swept other developing world countries in the 1980s and 1990s, which has produced a very poor standard of living for citizens. These practices have, in turn, created widespread resentment and dissatisfaction among citizens who importantly lack a legal and non-violent means to express their displeasure with the status quo (see also Windsor, 2003).

The undemocratic regimes of the Middle East have furthermore compounded the problem by trying to wield public rage as a political tool through state-run media, state-sponsored public demonstrations and state-controlled political associations. In the absence of a free press or freedom of public expression, an 'epistemological retardation' pervades political discourse fostering a mood of paranoia, legitimizing political violence and giving credence to conspiracy stories in which the United States and its allies are perpetual villains. In these societies, public grievances are not addressed and are therefore allowed to fester to the point that citizens turn to extremist actors for relief. The dictatorial nature of the regime furthermore retards the public virtues of political moderation and compromise, which are necessary ingredients of non-violent political expression (Muravchik, 2001).

Non-partisan, academic studies of the relationship between politically and economically closed societies and terrorism generally do not support the model Muravchik outlines. In fact, most empirical studies of terrorism tend to demonstrate a positive relationship between political democracy and terrorism. The relationship between terrorism and macroeconomic policies of states whether they are liberal or state-dominated - has not been empirically analyzed and so much less is known about how promotion of economic freedom might affect terrorism.

Eubank and Weinberg (1994, 2001) and Schmid (1992) argue that rather than serving as a bulwark against terrorism, democratic governance exacerbates terrorist activity by providing a wide range of avenues through which radicals can advance their political agendas through, 'propaganda by deed'. Schmid (1992) explains that an open and free media - a central quality of democratic governance — facilitates the communication objective that all terrorist groups have while the system of legal rights institutionalized in most democracies more effectively shield terrorist suspects and perpetrators from detection, apprehension and prosecution. Democracies also facilitate the 
unrestricted and unmonitored movement of people, creation of free associations and acquisition of weapons; all of which assist terrorist groups. Moreover, the legitimacy of democratic government rests ultimately on the public's perception of how well it can protect its citizens, and in a democracy citizens can punish elected officials at the ballot box for failure to protect the public. This quality of public responsiveness makes democracies more willing to negotiate with terrorists.

In two statistical studies of the presence of terrorist groups in countries, Eubank and Weinberg $(1994,2001)$ validated these propositions in observing that from World War II to 1987, more terrorist groups were found in democracies than in non-democracies. The researchers also found that no matter how durable or stable the democracy in question is, it is more likely to have terrorist activity in it than a non-democracy. Compatible results were produced by Piazza (2007) in a time-series analysis of Middle Eastern states and to an extent by Li (2004), although his study did find that while specific components of democracy, such as government executive constraints, increased the probability of terrorism, democratic participation reduced it. Eyerman (1998) adds complexity to the question in his empirical study of terrorist acts from 1968 to 1986. Using a series of statistical analyses, he found that two types of states were most impervious to terrorist attacks, well-established democracies and entrenched dictatorships. However, new non-consolidated democracies were actually more likely to experience terrorism in Eyerman's study, producing a nonlinear relationship between terrorism and degree of democracy and dictatorship.

Addressing the hypothesis that terrorism thrives in economically illiberal societies, Li and Schaub (2005) devised a series of pooled time-series multiple regression analysis models using a sample of terrorist incidents in 112 countries between 1975 and 1997, and determined that international trade and investment (foreign direct and portfolio) were negative predictors of terrorism in as much as increased globalization of trade and investment spurs economic development. These findings are only a partial vindication of the contention that lack of economic freedom promotes terrorism because the investigators only consider one element of free market economic policy - state policies restricting international trade and investment and the global integration of national economies. Li and Schaub, it is important to note, also included a control variable measuring democratic governance, derived from the POLITY IV database, and did not find it to be significant in any of the 16 models run. However, two qualitative academic studies do provide partial support for at least the argument that free markets reduce terrorism. Kitschelt (2004), in a descriptive study, associates Islamist terrorism with societies that have failed to support the creation of capitalist market systems and have eschewed economic globalization. Although his study is focused on the Middle East, he states that 
this negative relationship between adoption of capitalism and integration in the world economy and terrorism may also apply to other regions of the world. Bergensen and Lizardo (2004), using a world systems approach, argue that waves of terrorist activity occur when globalization surges in the countries of the semi-periphery as well as when the dominant hegemon suffers a decline.

\section{Analysis}

Although the Bush administration's explanation for the root causes of terrorism - that it is a byproduct of dictatorship and economically closed societies - may appear gauzy and under-theorized to scholars of terrorism and political violence, it does contain at least two testable hypotheses. They are:

Hypothesis 1: Democratic governance is negatively related to the incidence of international terrorism.

Hypothesis 2: Free market economic policies are negatively related to the incidence of international terrorism.

This study tests these two hypotheses using a set of negative binomial statistical regression models on 153 countries, the total number for which reliable data could be obtained, for the years 1986-2003, inclusive, the total number of years for which US State Department data on terrorist incidents and casualties due to terrorism are available on a country-to-country basis. Owing to the nature of the dependent variable, incidents of transnational terrorism, a negative binomial model is most appropriate. The distribution of terrorist incidents across the countries examined does not conform to a normal distribution while negative values cannot, by definition, be assigned to any observation, thus making an ordinary least squares (OLS) model inefficient. However, as a robustness check, unreported duplicate OLS models are run on the data and do not produce significantly different results. Furthermore, to address the issue of clustering around cases, robust standard errors are produced and reported and tests for multicollinearity are also performed, though are not reported. ${ }^{2}$ The countries included in the study are reported in the Appendix. The sources for and operationalization of variables used in the study are detailed in Table 1.

The dependent variable of the study is the total number of terrorist incidents that occurred in a country from 1986 to 2003. The variable is operationalized through an event-count coding of incidents of terrorism described in the 'Chronology of Significant Terrorist Incidents' found in the State Department's Patterns of Global Terrorism serial publication. Patterns is widely regarded as an authoritative source for data on terrorism, but in June of 2004 it was criticized for publishing a miscount of the total number of global terrorist events in the 2003 edition (Krueger and Laitin 2004). The miscounted 2003 edition has since been corrected and the updated figures are used in this study. 
Table 1 Variables, operationalization and sources

Variable Operationalization Source

Terrorism incidents

Democracy $(\mathrm{FH})$

Democracy

(polity IV)

Economic freedom

(Heritage)

Economic freedom (EFW)

Human development

index

Population

Geographic area

Regime durability

Repression capacity

index

State failures

Muslim country
Total number of terrorist attacks originating in a country, 1986 to 2003.

Average of political rights ('PR') and civil liberties ('CL') indexes for each country, 1986 to 2003.

Average 'Polity' scores for each country, 1986 to 2003.

Average Index of Economic Freedom measures from 1995 to 2003 for each country.

Average of 'Chain-Linked' Economic Freedom indexes 1985, 1990, 1995, 2000 and 2002 per country.

Average Human Development Index Scores from 1986 to 2003 per country.

Natural log of national population per country, 1986 to 2003. Natural log of total geographic surface area per country, 2000. Number of regime changes per country, 1986 to 2003 derived from 'Durable' indicator of Polity IV database.

[(Total Armed Forces in 1,000s) * (Total Military Budget in billions \$ US)] / [(Population in Millions)

* (Geographic Surface Area in millions of square kilometers)]

Number of state failures per country, 1986 to 2003.

Dummy variable coded ' 1 ' for countries with a majority or plurality of Muslims.
State Department. Patterns of Global Terrorism. Various years.

Freedom House. 2004. Annual Freedom in the World Country Scores 1972 through 2003.

Marshall, M. G. and Jaggers, K. 2004. POLITY IV Project: Political Regime Characteristics and Transitions. Heritage Foundation. Index of Economic Freedom (past scores). Data downloaded from: http://www.

heritage.org/research/features/index/downloads.cfm

Gwartney, J., Lawson, R. and Emerick, N. 2004. Economic Freedom of the World 2003.

United Nations Development Program. Human Development Report. Various years.

Ibid.

Ibid.

Marshall, M. G. and Jaggers, K. Polity IV Project: Political Regime Characteristics and Transitions, 1800-2002.

[Armed Forces, Military Budget, Population] United Nations Development Program. Human Development Report. Various years. [Geographic Surface Area] Allen, J. L. 2002. Atlas of World Politics.

Goldstone, J. et al. State Failure Task Force Report: Phase III Findings. Downloaded from: http://www. cidcm.umd.edu/inscr/stfail/sfdata.htm

State Department. CIA World Factbook. Downloaded from: http://www.odci.gov/cia/publications/factbook/ index.html 
For the analysis, incidents of terrorism are operationally defined in the same manner as that found in Title 2 of the United States Code, Section 2656f(d) whereby, "[t]he term "terrorism" means premeditated, politically motivated violence perpetrated against non-combatant ${ }^{3}$ targets by sub national groups or clandestine agents, usually intended to influence an audience' (US Department of State, 2001, 17). Therefore, each time a single terrorist attack is mentioned in Patterns of Global Terrorism, a terrorist incident is registered for the country where it occurred and the year that it occurred. In the case of a terrorist incident that begins in one country and terminates in a second or third, the incident is allocated to the country where the event originated; though cases of this sort account for less than $5 \%$ of the total data set. All incidents are recorded based on the country of occurrence, not the nationality or national legal status of the perpetrator.

There are four independent variables that are used to measure political and economic freedom in a country. The first, labeled Democracy $(F H)$, is an average from 1986 to 2003 of two indices created by Freedom House, a nonpartisan think tank, which measures the degree to which a country exhibits political freedom, measured as free and fair elections, and civil liberties. Both of these indexes range from ' 1 ' indicating countries that are completely free to ' 7 ' indicating countries that are completely unfree. For the purpose of this analysis, the average index score for a country is subtracted from 8 so that countries rated as 'free' by Freedom House are scored higher than those that are rated 'not free' to ease interpretation of the results. The Freedom House data have come under some criticism by scholars because of its decision to change its classification scheme - it classifies countries as 'Free', 'Partially Free' and 'Not Free' by defining ranges within the index — in the 1980s by a half-point. Therefore, a second regime type indicator, labeled Democracy (Polity IV), is also included. Democracy (Polity IV) is operationalized as an average of the 'Polity' score for 1986-2003, a measure of the degree of autocracy or democracy a regime exhibits. The Polity score ranges from ' 10 ' indicating countries that are established and complete political democracies to ' -10 ' indicating countries that are complete autocracies. Unlike Democracy (FH) above, Democracy (Polity IV) is coded without any modification.

The third and fourth main independent variables are measures of economic freedom or the degree to which the economic policies of a country are judged to be laissez-faire and free-market-oriented. Economic Freedom (Heritage) is the Index of Economic Freedom developed by the conservative Heritage Foundation think tank and published on their website. This index measures the degree of economic freedom in a country from 1995 to 2003 using 10 indicators evaluating government regulation of business, trade, investment, monetary policy, labor and property rights along with measurements of government corruption. The Index of Economic Freedom ranges from 0, no measurable 
level of economic freedom, to 100, perfect economic freedom. A significant limitation of the Index of Economic Freedom is that it only includes measurements of the years 1995-2003, thus presenting an incomplete picture of the status of economic freedom in the country, and is missing data on key states. A second variable measuring economic freedom is therefore also included: Economic Freedom ( $E F W$ ), a measure that utilizes the 1985, 1990, 1995, 2000 and 2002 'Chain-Linked' indexes of economic freedom presented in Gwartney, Lawson and Emerick's Economic Freedom of the World published by the conservative Fraser Institute. $E F W$ ranges from ' 10 ' indicating a country with relatively small government expenditures, little economic regulation, sound property rights, few capital controls, and openness to international trade and investment to a ' 1 ' indicating a country that is restrictive with regards to these qualities.

The study also includes a host of control variables, some of which are found in other quantitative studies of terrorism (see Li and Schaub (2005) for example). Level of economic development is controlled for by including the Human Development Index, a UNDP-constructed measurement that combines per-capita gross domestic product, literacy rate and life expectancy. Population and the total national Geographic Area, both natural logs of the national population and geographic area statistics, are also included. Three variables that measure various aspects of the state are also included. Regime Durability measures the number of regime changes experienced by the country in the timeframe, using data from the Polity IV database. Repression Capacity Index is a coefficient built by the author to measure the 'repressive capacity' of the state: the degree to which its 'repressive assets' - military personnel and military spending — are able to cover its 'security liabilities' — population and geographic surface area. State Failures is an event-count of years in which state failures occurred in a country from 1986 to 2003 using data from the 'State Failure Task Force Report' collected by Goldstone et. al. State failure is defined by the investigators in the State Failure Task Force Report as a type of severe political instability suffered by a government, which involves one or more of the following episodes: revolutionary wars, ethnic wars, adverse regime changes, and genocides and politicides. ${ }^{4}$ Failed states are those countries, like Somalia or the Democratic Republic of the Congo in the early to mid-1990s, where extreme political instability has robbed the state of one of its primary abilities as defined by Max Weber and others: to monopolize the legitimate use of force. Finally, a dummy variable is included for countries in the analysis that have a Muslim majority or plurality.

Expectations about these control variables are mixed. It is generally expected that countries with high Human Development indexes will experience fewer incidents of terrorism, although Piazza (2006) demonstrated that there is scant empirical evidence that poverty is a predictor of terrorism in cross-national 
analyses. Both Population and Geographic Area are expected to be positive predictors of terrorism as both represent significant structural impediments for states that aim to curb terrorism, and both are potential correlates for social cleavages and other sources of political conflict that might fuel terrorism. Both have also been found to be positive predictors of terrorism in previous studies (Li, 2004, Li and Schaub, 2005, Piazza, 2007). Regime Durability is expected to be a positive predictor of terrorism because countries characterized by frequent regime changes are likely to be beset with political instabilities that provide incentives and opportunities for terrorist groups to strike. The Repression Capacity Index is expected to be a negative predictor of terrorism because countries with high coefficients are able to mobilize considerable repressive capacity to deal with terrorist threats, thereby reducing the chances that terrorists will be successful or see the country as a lucrative target. State Failures is expected to be a positive predictor of terrorism for the same reason that Regime Durability is: countries beset with severe political instability are more likely to experience terrorism as avenues for non-violent political expression are closed, a desperate population is perhaps more receptive to radical political messages and states become less able to prevent terrorist attacks (Rotberg, 2002; Takeyh and Gvosdev, 2002).

Finally, the Muslim country dummy variable is expected to be a positive predictor of terrorism. Inclusion of this variable in the model is justified for three reasons. First and foremost, commentators such as Muravchik (2001), Kitschelt (2004) and Huntington (1996) focus on Muslim societies in their discussions of root causes of terrorism and frequently argue that Muslim societies are particularly prone to terrorism. Second, two Muslim countries - Iraq and Afghanistan - are the test cases for the Bush Administration efforts to combat terrorism by promoting democracy and economic reform, and much of the aid dedicated to promotion of political and economic liberalization is aimed at Muslim countries in the Middle East. Third, it is empirically true that Muslim countries, as a group, lag behind other countries in the developing world in terms of democratization and economic liberalization and therefore might be expected to be particularly prone to terrorism given the validity of the assumptions that underlie current US anti-terrorism policy. It however, has not previously been definitively substantiated through empirical studies that Muslim countries experience more terrorism than non-Muslim countries, though that is often the assumption made by policymakers, commentators and the general public. ${ }^{5}$

\section{Results}

A total of four regression models are run to test the two hypotheses using the preceding variables, the results of which are presented in Table 2. In all four of the models, the seven control variables are present. The models rotate 
Table 2 Political freedom, economic freedom and terrorism, 1986-2003

\begin{tabular}{|c|c|c|c|c|}
\hline Models & 1 & 2 & 3 & 4 \\
\hline Democracy (FH) & $0.254(0.154)$ & $0.288(0.135)^{*}$ & & \\
\hline Democracy (Polity IV) & & & $0.065(0.035)$ & $0.070(0.032)^{*}$ \\
\hline Economic freedom (Heritage) & $-0.002(0.014)$ & & $0.002(0.012)$ & \\
\hline Economic freedom (EFW) & & $-0.191(0.169)$ & & $-0.132(0.159)$ \\
\hline Human development index & $-0.000(0.001)$ & $0.000(0.001)$ & $-0.000(0.001)$ & $0.000(0.001)$ \\
\hline Population & $0.485(0.147)^{* *}$ & $0.506(0.148)^{* *}$ & $0.474(0.146)^{* *}$ & $0.494(0.149)^{* *}$ \\
\hline Geographic area & $-0.048(0.135)$ & $-0.055(0.134)$ & $-0.063(0.134)$ & $-0.070(0.134)$ \\
\hline Regime durability & $-0.118(0.173)$ & $-0.125(0.171)$ & $-0.144(0.165)$ & $-0.162(0.166)$ \\
\hline Repression capacity index & $0.000(0.000)$ & $0.000(0.000)$ & $0.000(0.000)$ & $0.000(0.000)$ \\
\hline State failures & $0.119(0.026)^{* * *}$ & $0.111(0.026)^{* * *}$ & $0.116(0.027)^{* * *}$ & $0.107(0.027)^{* * *}$ \\
\hline Muslim country & $0.923(0.392)^{*}$ & $0.982(0.360)^{* *}$ & $0.962(0.388)^{*}$ & $0.977(0.366)^{* *}$ \\
\hline Constant & $1.480(1.406)$ & $2.059(1.606)$ & $2.266(1.454)$ & $2.937(1.669)$ \\
\hline Wald $\chi^{2}$ & 86.56 & 94.26 & 84.95 & 89.78 \\
\hline$N$ & 146 & 149 & 146 & 149 \\
\hline
\end{tabular}

Negative binomial regression analysis results. Robust standard errors in parentheses.

*** Indicates significance at 0.000 level; ** indicates significance at 0.01 level; * indicates significance at 0.05 level. 
Democracy (FH), Democracy (Polity IV), Economic Freedom (Heritage) and Economic Freedom ( $E F W$ ) as independent variables. The central findings of the analyses are twofold: First, there is an inconsistent relationship between regime type and the incidence of transnational terrorism. The Freedom House measure of democratic rule is shown to be a significant but positive predictor of terrorism in model 2, a replication of findings by Eubank and Weinberg $(1994,2001)$ and others, but is not significant in any of the other models. The Polity IV measure of democracy is also significant in only one model, model 4. These findings do not support the contention that democratic rule reduces the incidence of terrorism. In fact the, albeit inconsistent, evidence produced suggests that the opposite is true. Second, none of the measurements of economic freedom, neither the Heritage Foundation variable nor the Economic Freedom in the World variable, are significant predictors of terrorism. They appear to be independent of the incidence of transnational terrorism.

However, a couple of the control variables are significant. Across all of the models, the national population $\log$ is a significant, positive predictor of terrorism as expected. Muslim countries are statistically more likely to experience transnational terrorism than non-Muslim countries as Muslim is a significant positive predictor across all four models. Finally, the variable measuring state failures is a significant positive predictor of terrorism across all of the models, suggesting that states that experience higher incidents of state failures are more likely to experience transnational terrorism.

The results of the main statistical models are echoed in the simple descriptive statistics displayed in Table 3. In this table, the average incidence of transnational terrorism is reported by groups of states classified by different qualities. Globally, states averaged 10.7 terrorist attacks for the period 19862003. Non-democratic countries, classified as such using both the Freedom House and Polity IV data, have a lower average categorical rate of terrorism than the global average. Though it is true that countries qualified by illiberal economic systems on average have higher rates of terrorism than the global rate, it is not markedly higher. Countries classified using the Heritage Foundation's Index of Economic Freedom's data experienced only 1.7 more terrorist attacks on average than all states, and experienced 0.9 fewer attacks than did Muslim countries. The countries below the median value using the Economic Freedom in the World data - those that are the 'least free' experienced significantly more terrorism on average than the typical state, but significantly less than states experiencing at least one instance of state failure. $69.7 \%-1,148$ out of 1,646 - of all terrorist attacks registered in the database from 1986 to 2003 occurred in countries that experienced some level of state failure.

These results fail to provide empirical support for two hypotheses tested in this study: that democratic countries are less likely to experience transnational 
Table 3 Illiberal countries and terrorism, 1986-2003

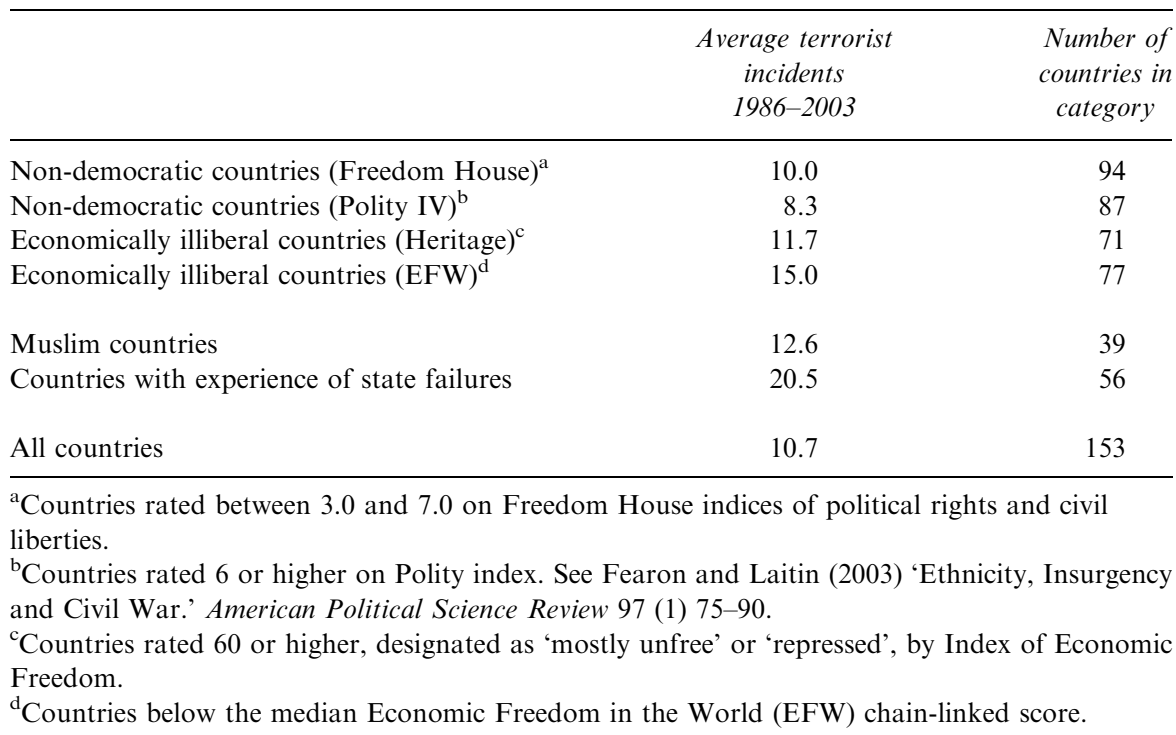

terrorism and that economically free countries are less likely to experience transnational terrorism. These results cut to the root of the assumptions on which current US anti-terrorism policy rests - that terrorism is the product of illiberal political and economic systems - and instead find population, political stability and possibly religious demographic factors as more important predictors of terrorism.

\section{Failed States and Terrorism}

These results yield five interesting conclusions: First, the analysis fails to provide clear evidence that the promotion of democracy and free market economics is a potential panacea for terrorism. In fact, in validating previous empirical analysis on the subject it provides evidence that promoting democracy might even increase the incidence of terrorist attacks in some countries. The study also unearths no evidence that promotion of free market economic reform will have any substantial effect on terrorism. Second, countries with a majority or plurality of Muslims are more likely to be plagued by terrorist attacks. This is a result that requires further study - possibly a fuller consideration of the role that region and 'Huntingtonian civilizations' play as predictors of terrorism - before any concrete conclusions can be 
reached about it. Third, while it makes theoretical sense that a country's ability to project internal repression plays an important role in determining the degree to which it experiences terrorism - that is to say countries with small populations and small geographic areas that are governed by states with larger military assets should be best endowed to resist terrorist attacks - the results fail to provide support for this supposition. The Repression Capacity Index is not significant in any of the models and while population is a significant predictor across all of the models, geographic area is not. Fourth, level of economic development appears to be unrelated to terrorism. This is a reproduction of findings by several previous studies and underscores the idea that poorer and lesser developed countries are no more likely to experience terrorism than developed countries. Economic development is a worthy goal that undoubtedly yields many, many positive results. There is no evidence that reduction of terrorism is one of them.

The fifth and final conclusion involves the relationship between political stability in a country and the incidence of terrorism. The results do not demonstrate that instability in the form of frequent regime changes is a significant predictor of terrorism. But the results do suggest that countries plagued by state failures are more likely to experience terrorism than countries that do not. The relationship of state failures to terrorism is not new to policymakers or academics. United States Senator Chuck Hagel (R-NE) argued in an article published in Foreign Policy that the most severe threat to US security at home and abroad comes from failed states, 'Terrorism finds sanctuary in failed or failing states...' (Hagel, 2004, 65). These countries face enormous challenges due to demographic pressures, economic and social collapse and numerous security challenges arising from wars and civil and ethnic conflicts. Failed and failing states cannot effectively meet these challenges.

Robert I. Rotberg, director of the Belfer Center's Program on Intrastate Conflict and Conflict Resolution at Harvard's Kennedy School of Government and former advisor to the US Secretary of State, explains that failed states, 'can no longer deliver positive political goods to their people,' lack strong governing institutions, and cannot adequately manage large conflicts in society such as sectarian violence and cannot control the movement of people across or within their own borders (Rotberg, 2002, 85). Failed states lack the capacity to quell criminal activity and they cannot provide basic economic stability for citizens. This failure to deliver essential political goods - security, education, economic stability, etc. - damages the legitimacy of the state and erodes the civil bases on which mainstream political behavior can thrive, propelling individuals into terrorism.

A small, qualitative scholarly literature further explains the relationship between failed states and international terrorism. Takeyh and Gvosdev (2002) sketch out a comprehensive explanation for why failed states are attractive as 
bases of operation for terrorists and terrorist groups. They note that US intelligence reports indicated that the Al-Qaeda terrorist network, after being deprived of its home base in Afghanistan with the collapse of the Taliban regime in 2001-2002, sought to move operations to Somalia, Indonesia, Chechnya, Bosnia, Lebanon and Kosovo - all of which can be described as failed or failing states that cannot adequately police or monitor the activities of militants and lack 'vibrant civil societies' that might stymie the influence of militants in mainstream life.

Failed or failing states provide large amounts of territory for terrorist operations that can be used for training, arms depots and communications and revenue-generating activities that go beyond the limited network of 'safe houses' they can construct in countries with stronger states. This creates the phenomenon of 'stateless areas' within countries experiencing state failure wherein substantial regions of the country are left unpoliced by the security forces of the central government, providing operational and political space for terrorists, or where non-spatially defined segments of a nation's polity cannot be penetrated by state security forces allowing terrorist activities to prosper unhampered. The spatial variety of the stateless area problem suffered by failed states would be exemplified by Colombia, Yemen or Afghanistan, all of which have substantial amounts of national territory within which the central government cannot project power. The non-spatial variant could be exemplified by Saudi Arabia. The Saudi state, a heavy spender on military equipment since the early 1990s, is able to project power throughout the geographical confines of the Kingdom, but contains a impenetrable network of civil society associations, the waqfs or Muslim charitable funds, protected by powerful Saudi political actors, some of which exhibit a radical political agenda and serve as financiers and assistants to terrorist groups abroad (Kahler, 2002).

Frequently, political elites within failed states are willing to tolerate the presence of large-scale terrorist operations within national borders in exchange for political support or terrorist services during times of political turmoil. Failed states, as previously mentioned, lack adequate or consistent lawenforcement capabilities, thus permitting terrorist organizations to develop extra-legal fundraising activities such as smuggling or drug trafficking. Failed states, which lack the economic performance or civil society to reinforce lawabiding civic life, also provide reserves of potential recruits for terrorists which may not be incompatible with some of the neo-conservative hypothesis regarding terrorism. Finally, the authors note that failed states retain, 'the outward signs of sovereignty' (Takeyh and Gvosdev, 2002, 100), thus providing terrorist groups with the necessary legal documentation (passports or end user certificates for arms acquisition) and legal cover from external policing efforts. All of these make failed states potential precipitants of terrorism. 


\section{Conclusion}

If this study lends weight to the suggestion that state failure might be examined by policymakers as a possible cause of transnational terrorism and that the current focus on promoting democracy and free markets might be reconsidered, a considerable change in official spending priorities is placed on the table. While the Bush Administration has offered vague rhetorical support for the need to address the problem of state failure in the context of anti-terrorism policy (National Security Council, 2006, 15; Rice, 2006; US Department of State, 2003, 23) it has provided a paucity of resources for efforts to alleviate state failure. Of the US $\$ 16.2$ billion allocated for non-US military and nonHomeland Security expenditures in the Global War on Terror, nearly 11 billion was directed to democracy promotion, economic aid and 'good government' economic reform abroad. Of the remaining 5.2 billion, 4.7 billion were subsidies of the Afghan and Iraqi militaries, leaving just US $\$ 500$ for the promotion of physical security and political stability worldwide (White House, 2007). These figures help to illustrate the positioning of state failure alleviation $v i s-a$-vis other US foreign policy imperatives in the War on Terror. They also illustrate the level of investment that currently exists in the idea that democracy and free market reform are the prime antidotes to terrorism.

\section{Notes}

1 However, Thomas Carothers (2003) cautions against reading too much into the Bush Administrations' declared policy shift towards supporting democracy throughout the globe. He notes that the Administration still retains a pseudo-realist character to it, despite the idealist rhetorical flair, by backsliding on earlier demands for democratization in Pakistan, Indonesia, Malaysia, Kazakhstan, Khirgizia and Uzbekistan, quietly approving military coups in Venezuela and Haiti and excusing the non-democratic excesses of the Putin Administration in Russia. Carothers notes that the Bush administration has been most strident in its demands for democratic reform in the Arab World, and even within that subset has only taken action in Iraq.

2 Results of all unreported models and tests are available from the author upon request.

3 Note that the definition of 'non-combatant' used by the US Department of State includes, in addition to civilians, military personnel who are either not armed or not on duty at the time of the incident.

4 The investigators define the four components of 'State Failure' in the following manner: (1) Revolutionary war refers to, 'Episodes of sustained violent conflict between governments and politically organized challengers that seek to overthrow the central government, to replace its leaders or to seize power in one region.' (2) Ethnic war refers to, 'Episodes of sustained violent conflict in which national, ethnic, religious or other communal minorities challenge governments to seek major changes in status.' (3) Adverse regime changes are, 'Major, abrupt shifts in patterns of governance, including state collapse, periods of severe elite or regime instability and shifts away from democracy toward authoritarian rule.' (4) Genocides and politicides are, 'Sustained policies by states and their agents, or, in civil wars, by either of the contending authorities that result in the deaths of a substantial portion of a communal or political group.' See Jack A. Goldstone et al. 
(2000) 'State Failure Task Force Report: Phase III Findings.' Accessible at: www.cidcm.umd.edu/ incr/stfail/SFTF\%20Phase\%20III\%20Report\%20Final.pdf (p. V).

5 When countries in the analysis are assigned dummy variables indicating the major 'civilization' they belong to according to the definition of civilizations provided by Huntington (1996), the following Pearson's $r$ correlation coefficients are found:

\begin{tabular}{lcccccrr}
\hline Civilization & $\begin{array}{l}\text { Democracy } \\
\text { (Polity IV) }\end{array}$ & $\begin{array}{l}\text { Democracy } \\
\text { (FH) }\end{array}$ & $\begin{array}{l}\text { Economic } \\
\text { freedom } \\
\text { (EFW) }\end{array}$ & $\begin{array}{l}\text { Economic } \\
\text { freedom } \\
\text { (Heritage) }\end{array}$ & $\begin{array}{l}\text { Terrorist } \\
\text { incidents }\end{array}$ & $\begin{array}{l}\text { Terrorist } \\
\text { casualties }\end{array}$ & $N$ \\
\hline Islamic & $-0.529 * * *$ & $-0.549^{* * *}$ & $-0.229 * *$ & $-0.276^{* *}$ & 0.039 & -0.018 & 39 \\
Western & $0.539^{* * *}$ & $0.483^{* * *}$ & $0.496^{* * *}$ & $0.480^{* * *}$ & 0.016 & 0.081 & 24 \\
African & $-0.303^{* * *}$ & $-0.320^{* * *}$ & $-0.281^{* * *}$ & $-0.269 * *$ & -0.076 & 0.029 & 31 \\
Confucian & -0.113 & -0.081 & 0.070 & -0.015 & -0.074 & -0.070 & 14 \\
Latin American & $0.219^{* *}$ & $0.294^{* * *}$ & -0.029 & 0.053 & -0.015 & -0.097 & 27 \\
Slavic & 0.124 & 0.132 & $-0.181^{*}$ & -0.039 & -0.103 & -0.081 & 18 \\
Hindu & 0.064 & 0.108 & 0.022 & -0.080 & $0.372 * * *$ & $0.269^{* *}$ & 4 \\
\hline
\end{tabular}

Two-tailed significance.

*** indicates significance at the 0.000 level; ** indicates significance at the 0.01 level; * indicates significance at the 0.05 level.

The Islamic countries are indeed the least free politically and economically and stand out among the other countries sorted into Huntington's civilizations. However, at least in these simple bivariate tests the Islamic countries are no more likely to experience terrorism than are any countries of the other civilizations.

\section{References}

Bergensen, A.J. and Lizardo, O. (2004) 'International Terrorism and the World System', Sociological Review 22(1): 38-52.

Carothers, T. (2003) 'Promoting Democracy and Fighting Terror', Foreign Affairs 82(1): 84-97.

Diamond, L. (2002) 'Winning the War on Terrorism', Policy Paper No. 1. Institute for Global Democracy. March.

Eubank, W.L. and Weinberg, L. (1994) 'Does Democracy Encourage Terrorism?' Terrorism and Political Violence 6(4): 417-443.

Eubank, W.L. and Weinberg, L. (2001) 'Terrorism and Democracy: Perpetrators and Victims', Terrorism and Political Violence 13(1): 155-164.

Eyerman, J. (1998) 'Terrorism and Democratic States: Soft Targets or Accessible Systems', International Interactions 24(2): 151-170.

Fraser Institute. (2002) 'Media Release: Nobel Laureates Call on G-8 to Focus on Economic Freedom', 25 June, Downloaded from, www.freetheworld.com/press062502.html.

Hagel, C. (2004) 'A Republican Foreign Policy', Foreign Affairs. 83(4): 64-76.

Huntington, S.P. (1996) The Clash of Civilizations and the Remaking of World Order, New York: Simon and Schuster.

Kahler, M. (2002) 'Networks and Failed States: September 11 and the Long Twentieth Century', Paper presented at the annual meeting of the American Political Science Association, Boston. 
Kitschelt, H. (2004) 'Origins of International Terrorism in the Middle East', Interationale Politik und Gesellschaft 1: 159-188.

Klein, N. (2004) 'Baghdad Year Zero', Harper's Magazine. September.

Krueger, A.B and Laitin, D.D. (2004) 'Misunderestimating' Terrorism', Foreign Affairs 83: 5.

Li, Q. (2004) 'Does Democracy Promote or Reduce Transnational Terrorist Incidents?' Journal of Conflict Resolution 49(2): 278-297.

Li, Q. and Schaub, D. (2005) 'Economic Globalization and Transnational Terrorism: A Pooled Time-Series Analysis', Journal of Conflict Resolution 48(2): 230-258.

Muravchik, J. (2001) 'Freedom and the Arab World', The Weekly Standard,, December 31.

National Security Council. (2006) 'Strategy for Winning the War on Terror', Public Document, http://www.whitehouse.gov/nsc/nsct/2006/sectionV.html.

Piazza, J. (2006) 'Rooted in Poverty?: Terrorism, Poor Economic Development and Social Cleavages', Terrorism and Political Violence 18: 219-237.

Piazza, J. (2007) 'Draining the Swamp: Democracy Promotion, State Failure and Terrorism in 19 Middle Eastern Countries', Studies in Conflict and Terrorism 30(6): 521-539.

Powell, C. (2002) Speech before the Heritage Foundation. 12 December. Washington, DC.

Rice, C. (2006) 'Transformational Diplomacy', Public address, Georgetown University. 18 January, http://www.state.gov/secretary/rm/2006/59306.htm.

Rotberg, R.I. (2002) 'The New Nature of Nation-State Failure', The Washington Quarterly 25(3): $85-96$.

Schmid, A. (1992) 'Terrorism and Democracy', Terrorism and Political Violence 4: 4.

Shays, C. (2003) 'Free Markets and Fighting Terrorism', Editorial. Washington Times. 10 June.

Takeyh, R. and Gvosdev, N. (2002) 'Do Terrorist Networks Need a Home?' The Washington Quarterly 25(3): 97-108.

Voice of America. (2005) 'Afghanistan's March to Democracy', 17 October 2005.

White House. (2002) The National Security Strategy of the United States, Washington, DC: Office of the President.

White House. (2007) 'Advancing Freedom and Democracy Around the World', Fact Sheet, Office of the Press Secretary, 5 June, http://wwwstate.gov/p/eur/rls/fs/85992.htm.

United Nations Development Program. (2002) The Arab Development Report 2002, New York, NY: United Nations Publications.

US Department of State. (2001) Patterns of Global Terrorism, Washington, DC: Office of Counterterrorism.

US Department of State. (2005) Supporting Human Rights and Democracy: The US Record 20042005, Washington, DC: US Bureau of Democracy, Human Rights and Labor, http:// www.state.gov/g/drl/rls/shrd/2004/.

US State Department. (2003) 'National Strategy for Combating Terrorism', Public Document. February, http://www.state.gov/documents/organization/60172.pdf.

Windsor, J.L. (2003) 'Promoting Democratization Can Combat Terrorism', Washington Quarterly 26: $43-58$. 


\section{Appendix: List of Countries Included in the Analysis}

\begin{tabular}{|c|c|c|}
\hline Afghanistan & Albania & Algeria \\
\hline Angola & Argentina & Australia \\
\hline Austria & Azerbaijan & Bahamas \\
\hline Bahrain & Bangladesh & Barbados \\
\hline Belarus & Belgium & Belize \\
\hline Benin & Bolivia & Bosnia \\
\hline Botswana & Brazil & Bulgaria \\
\hline Burma (Myanmar) & Burundi & Cambodia \\
\hline Cameroon & Canada & Central African Republic \\
\hline Chad & Chile & China \\
\hline Colombia & Congo, Republic of & Costa Rica \\
\hline Cote d'Ivoire & Croatia & Cuba \\
\hline Cyprus & Czech Republic & Denmark \\
\hline Djibouti & Dominica & Democratic Republic of Congo \\
\hline Ecuador & Egypt & El Salvador \\
\hline Eritrea & Estonia & Ethiopia \\
\hline Fiji & Finland & France \\
\hline Gabon & Georgia & Germany \\
\hline Ghana & Greece & Guatemala \\
\hline Guinea & Guyana & Haiti \\
\hline Honduras & Hungary & Hong Kong \\
\hline Iceland & India & Indonesia \\
\hline Iran & Iraq & Ireland \\
\hline Israel & Italy & Jamaica \\
\hline Japan & Jordan & Kazakhstan \\
\hline Kenya & Kuwait & Kyrgyz Republic \\
\hline Laos & Latvia & Lebanon \\
\hline Liberia & Libya & Lithuania \\
\hline Luxembourg & Macedonia & Madagascar \\
\hline Malawi & Malaysia & Mali \\
\hline Malta & Mauritius & Mexico \\
\hline Morocco & North Korea & Namibia \\
\hline Nepal & Netherlands & New Zealand \\
\hline Nicaragua & Niger & Nigeria \\
\hline Norway & Oman & Pakistan \\
\hline Panama & Papua New Guinea & Paraguay \\
\hline Peru & Philippines & Poland \\
\hline Portugal & Romania & Russia \\
\hline Rwanda & South Korea & Saudi Arabia \\
\hline Senegal & Serbia and Montenegro & Sierra Leone \\
\hline Singapore & Slovak Republic & Slovenia \\
\hline Somalia & South Africa & Spain \\
\hline Sri Lanka & Suriname & Sudan \\
\hline Sweden & Switzerland & Syria \\
\hline
\end{tabular}


James A. Piazza

Appendix Continued

Taiwan

Thailand

Tunisia

United Arab Emirates

United Kingdom

Uzbekistan

Yemen

Tajikistan
Togo
Turkey
Uganda
United States
Venezuela
Zambia

Tanzania

Trinidad and Tobago

Turkmenistan

Ukraine

Uruguay

Vietnam

Zimbabwe 